CLINICAL STUDY

\title{
Association of glucocorticoid receptor polymorphism A3669G with decreased risk of developing diabetes in patients with Cushing's syndrome
}

\author{
Laura Trementino, Gloria Appolloni, Carolina Concettoni, Marina Cardinaletti, Marco Boscaro \\ and Giorgio Arnaldi \\ Division of Endocrinology, Polytechnic University of Marche, Via Conca 71, 60020 Torrette di Ancona, Italy \\ (Correspondence should be addressed to G Arnaldi; Email: arnaldi.giorgio@libero.it)
}

\begin{abstract}
Objective: Glucocorticoid receptor (GR) polymorphisms alter glucocorticoid (GC) sensitivity and have been associated with altered metabolic profiles. We evaluate the prevalence of the four GR (NR3C1) polymorphisms BclI, N363S, ER22/23EK, and A3669G in patients with Cushing's syndrome (CS) compared with healthy controls (HC) and we investigate their role in the development of metabolic abnormalities in patients with CS according to their hormonal profile.

Patients and methods: Sixty-one patients with CS and 71 sex- and age-matched HC were genotyped. Results: BclI variant was markedly higher in patients with CS compared with $\mathrm{HC}(62$ vs $41 \%, P<0.05)$ while no significant differences were found among other polymorphisms. A very low frequency of N363S and the ER22/23EK was observed.

In CS patients, despite the significantly increased levels of morning serum cortisol in BclI carriers compared with wild type no clinical or metabolic differences were found.

In contrast, A3669G GR carriers showed a significantly reduced prevalence of type 2 diabetes mellitus compared with wild type (19 vs $68 \%, P=0.001$ ) despite the higher levels of both serum morning $(21.7 \pm 6$ vs $27.3 \pm 8.6 \mu \mathrm{g} / \mathrm{dl}, P=0.009)$ and midnight cortisol $(18.8 \pm 5.8$ vs $24.0 \pm 8.0 \mu \mathrm{g} / \mathrm{dl}$, $P=0.01$ ). The negative association between diabetes and A3669G GR polymorphism remained significant when data were adjusted for potential confounding factors.

Conclusions: The A3669G polymorphism of the GR gene plays a protective role in patients with CS, attenuating the effects of GC excess on glucose metabolism as shown by their reduced risk of diabetes.
\end{abstract}

European Journal of Endocrinology 166 35-42

\section{Introduction}

Endogenous Cushing's syndrome (CS) is an uncommon disorder resulting from chronic exposure to increased levels of glucocorticoids (GCs) frequently due to a pituitary tumor (Cushing's disease (CD)) hypersecreting ACTH or less frequently caused by independent adrenal overproduction of cortisol (adrenal CS (ACS)) (1-6).

Chronic GC excess is associated with metabolic complications such as central obesity, arterial hypertension, type 2 diabetes mellitus (T2DM), and dyslipidemia (7). Although all these conditions are common in patients with CS, their frequency is very different among patients suggesting the existence of variable sensitivity to GC, at least partially genetically determined, that plays a role in modulating the effect of cortisol excess on various tissues (8). In this respect, the glucocorticoid receptor $(G R)$ may be at least in part responsible for the variable response to GCs (9).
Several investigations have shown that polymorphisms of the GR (NR3C1) may be associated with altered sensitivity to GCs leading to negative or positive effect on metabolic profile (10).

In particular, the BclI and the N363S polymorphisms of the GR gene have been associated in the general population with an enhanced sensitivity to GCs and consequently to increased abdominal fat mass, higher cholesterol levels and hyperinsulinemia in obese carriers, and low bone mineral density (11-15).

In contrast, subjects with the ER22/23EK GR polymorphism show a relative GC resistance reflected in favorable metabolic parameters and body composition (16-18).

Finally, the A3669G GR polymorphism, a GR variant located in exon $\beta$, seems to be associated with an increased expression and stabilization of the dominantnegative splice variant GR- $\beta$. There is evidence that enhanced GR- $\beta$ expression results in greater inhibition 
of $G R-\alpha$ (the functional GR isoform) transcriptional activity, producing relative GC resistance (19-24). The presence of this polymorphism has been associated in the general population with increased inflammatory parameters and cardiovascular disease despite a more favorable lipid profile in men and body composition in women (25-26).

While the functional role of GR polymorphisms in the general population has been extensively investigated, data in patients with endogenous hypercortisolism are inconsistent.

Except for Szappanos et al. (27) who recently evaluated GR polymorphisms and bone metabolism in patients with endogenous hypercortisolism, and found increased skeletal sensitivity to GCs in patients with the BcII GR polymorphism, to our knowledge there are no studies on the role of GR polymorphisms on clinical and biochemical parameters in patients with CS.

The aim of this study, therefore, was to evaluate the prevalence of the four GR polymorphisms BclI, N363S, ER22/23EK, and A3669G in patients with CS compared with healthy controls (HC) and secondly to investigate the role of these genetic variants in the development of metabolic abnormalities in patients with CS.

\section{Patients and methods}

Sixty-one patients with a diagnosis of active and overt CS consecutively referred to our center from January 2000 to December 2010 were studied. The diagnosis of endogenous hypercortisolism and the differential diagnosis among CD, ectopic ACTH secretion, and ACS were based on clinical features and biochemical data according to the consensus statement and clinical practice guideline $(7,28)$. The diagnosis of $\mathrm{CD}$ was subsequently confirmed on pituitary surgery and/or post-operative clinical and biochemical resolution of hypercortisolism.

In all CS patients personal history was collected and a complete physical examination and biochemical and hormonal evaluation were performed.

All patients were genotyped for the presence of the four GR polymorphisms BclI, N363S, ER22/23EK, and A3669G and genotype distributions were compared with those of 71 age- and sex-matched HC. HC were recruited from patients referred to our center for thyroid evaluation and found to be disease free. Exclusion criteria for $\mathrm{HC}$ were a personal history of hypercortisolism. All CS and HC were of Caucasian origin.

\section{Clinical evaluation}

Anthropometric measurements included weight, height, and body mass index (BMI). A BMI $>30 \mathrm{~kg} / \mathrm{m}^{2}$ was considered as an index of obesity. According to international criteria (29), arterial pressure was measured in the right arm with subjects in a relaxed sitting position and the average of three measurements calculated. On the basis of ATPIII criteria (30), subjects with systolic blood pressure $\geq 130 \mathrm{mmHg}$ and/or diastolic blood pressure $\geq 85 \mathrm{mmHg}$ and/or on anti-hypertensive therapy were considered as affected by hypertension. Disease duration was estimated on the basis of date of onset of signs and symptoms of hypercortisolism.

\section{Biochemical evaluation}

The diagnosis of T2DM was made according to the criteria revised in 2003 by the American Diabetes Association (31) and patients were also considered diabetic if they were taking any hypoglycemic drugs. An oral glucose tolerance test (OGTT) was performed in all patients without a prior diagnosis of DM, not on therapy for the condition and with fasting plasma glucose $<126 \mathrm{mg} / \mathrm{dl}$. $\beta$-Cell function and insulin sensitivity were assessed by homeostasis model assessment (HOMA) according to Matthews et al. (32) by the following formulas: HOMA $\beta$-cell $(\%)=(20 \times$ fasting insulin $(\mathrm{mU} / \mathrm{l})) /($ fasting glucose $(\mathrm{mmol} / \mathrm{l})-3.5)$ and HOMA-IR $=($ fasting glucose $(\mathrm{mmol} / \mathrm{l}) \times$ fasting insulin $(\mathrm{mU} / \mathrm{l})) / 22.5$. On the basis of ATPIII criteria (30), hypercholesterolemia was defined as the presence of a total serum cholesterol $\geq 200 \mathrm{mg} / \mathrm{dl}$ and hypertriglyceridemia as the presence of serum triglycerides levels $\geq 150 \mathrm{mg} / \mathrm{dl}$. In our study, patients with hypercholesterolemia and/or hypertriglyceridemia and/or on lipidlowering treatment were considered as dyslipidemic.

\section{Hormonal evaluation}

All subjects had measurements of: i) morning serum cortisol and midnight serum cortisol after $24 \mathrm{~h}$ hospitalization; ii) $24 \mathrm{~h}$ urinary free cortisol (UFC; the average of two collections in almost all cases); and iii) serum cortisol levels after a $1 \mathrm{mg}$ dexamethasone suppression test (1 mg DST).

\section{Assays}

Chemiluminescent immunometric assays were used to measure serum cortisol (Advia Centaur; Bayer Diagnostics). Method sensitivity was $0.4 \mathrm{mg} / \mathrm{dl}$ and intra- and inter-assay variation coefficients of variation (CV) were 4.4 and $6.0 \%$ (normal range 5-23 $\mu \mathrm{g} / \mathrm{dl}$ for morning serum cortisol).

Twenty-four hours UFC was assessed by HPLC in accordance with the modified Santos-Montes method (intra-assay CV 7.73\%; normal range 9.2-45.2 $\mathrm{gg} / 24 \mathrm{~h})(33)$.

Plasma glucose, insulin levels, total serum cholesterol, serum triglycerides, low-density lipoprotein, and high-density lipoprotein were measured by standard procedures. 


\section{Genetic analysis}

DNA was isolated from whole blood by the use of a kit (Qiagen $\mathrm{GmbH}$ ). Two hundred nanograms of genomic DNA were amplified in $50 \mu$ reaction containing $1 \times$ buffer $(10 \mathrm{mM}$ Tris- $\mathrm{HCl}(\mathrm{pH} 8.8), 50 \mathrm{mM} \mathrm{KCl}$, $0.1 \%$ Triton $\mathrm{X}-100), 1.5 \mathrm{mM} \mathrm{MgCl}_{2}, 25 \mathrm{pmol}$ of specific primers, $0.8 \mathrm{mM}$ dNTPs, $1 \mathrm{U}$ units of Taq DNA polymerase (Finnzymes Oy, Espoo, Finland). The amplification conditions were: initial denaturation at $94{ }^{\circ} \mathrm{C}$ for $4 \mathrm{~min}$; 30 cycles of denaturation at $94{ }^{\circ} \mathrm{C}$ for $30 \mathrm{~s}$, annealing at $55^{\circ} \mathrm{C}$ for BclI, $58{ }^{\circ} \mathrm{C}$ for N363S, $56{ }^{\circ} \mathrm{C}$ for ER22/23EK, $55^{\circ} \mathrm{C}$ for GR-9 $\beta$ for $30 \mathrm{~s}$, and extension at $72{ }^{\circ} \mathrm{C}$ for $30 \mathrm{~s}$; followed by a final extension at $72{ }^{\circ} \mathrm{C}$ for $7 \mathrm{~min}$. Genomic DNA was amplified in a GeneAmp PCR System 2700 thermal cycler (Applied Biosystems, Foster City, CA, USA). Details of PCR primers are shown in Supplementary Table 1, see section on supplementary data given at the end of this article.

To determine genotypes of the Asn363Ser polymorphism, we digested the relevant PCR products at $65^{\circ} \mathrm{C}$ for $5 \mathrm{~h}$ with $4 \mathrm{U}$ Tsp509I and NE buffer 1 supplied by the manufacturer of the enzyme (New England BioLabs, Ipswich, MA, USA). The subsequent separation on $2 \%$ agarose gel of digestion fragments gave bands of 19 and 134 bp (Asn363 variant) and did not cut the PCR product (153 bp band) in the case of the Ser363 variant. An invariant band of 95 bp was seen in all samples.

Intron 2 primers were designed for a PCR product to include the BclI RFLP $\mathrm{C}$ to $\mathrm{G}$ mutation $646 \mathrm{bp}$ downstream of exon 2 . The genotypes were determined by digestion for $2 \mathrm{~h}$ at $50{ }^{\circ} \mathrm{C}$ with $15 \mathrm{UBClI}$ and NE buffer 3 supplied by the manufacturer of the enzyme (New England BioLabs) and subsequent separation on $2 \%$ agarose gels. The CC genotype produced two bands (221 and $117 \mathrm{bp}$ ), the CG genotype three bands (335 221 and $117 \mathrm{bp}$ ) while the GG genotype remained undigested.

To determine genotypes of the ER22/23EK, we digested the relevant PCR products at $37^{\circ} \mathrm{C}$ for $2 \mathrm{~h}$ with $5 \mathrm{U}$ MnlI and NE buffer 2 supplied by New England BioLabs. MnlI cleaves at $5^{\prime}-\mathrm{CCTC}(\mathrm{N}) 7-3^{\prime}$ and at $3^{\prime}-\mathrm{GGAG}(\mathrm{N}) 6-5^{\prime}$. Fragments were visualized with ethidium bromide on a 3\% agarose gel. The first mutation was silent, changing codon 22 from GAG to GAA, both coding for glutamic acid. The second mutation changed codon 23 from AGG to AAG, resulting in an amino acid change from arginine to lysine. The heterozygote genotype produced two bands (190 and $160 \mathrm{bp}$ ), the homozygote wild type genotype one band (160 bp).

To determine genotypes of GR-gene polymorphisms, the PCR products were treated with PCR Purification Kit (Qiagen $\mathrm{GmbH}$ ) and directly sequenced using on ABI BigDye Terminator Cycle Sequencing Kit (Applied Biosystems) with the primers listed in Table 1. Excess dye was removed by a DyeEx 2.0 Spin Kit (Qiagen $\mathrm{GmbH})$. The eluates were analyzed on an ABI Prism 310 Genetic Analyzer.
Table 1 Genotype distributions and allele frequencies of the glucocorticoid receptor gene polymorphisms in patients with Cushing's syndrome (CS) and healthy controls (HC).

\begin{tabular}{lll}
\hline & \multicolumn{2}{c}{ Genotype distribution } \\
\cline { 2 - 3 } & CS $(n=61)$ & $\mathrm{HC}(n=71)$ \\
\hline Bcl1 & $23(38 \%)$ & \\
CC & $34(56 \%)$ & $42(59 \%)$ \\
CG & $4(7 \%)$ & $23(32 \%)$ \\
GG & $0.34^{*}$ & $6(8 \%)$ \\
Allele frequency & $36(59 \%)$ & 0.24 \\
A3669G & $21(34 \%)$ & $42(59 \%)$ \\
AA & $4(7)$ & $24(34 \%)$ \\
AG & 0.21 & $5(7 \%)$ \\
GG & & 0.21 \\
Allele frequency & $58(95 \%)$ & $69(97 \%)$ \\
N363S & $3(5 \%)$ & $2(3 \%)$ \\
AA & 0 & 0 \\
AG & 0.02 & 0.01 \\
GG & & $70(99 \%)$ \\
Allele frequency & $55(95 \%)$ & $1(1 \%)$ \\
ER22/23EK & $2(3 \%)$ & 0 \\
GG & $1(2 \%)$ & 0.007 \\
GA & 0.03 & \\
AA &
\end{tabular}

*Significant difference $(P<0.05)$ between $\mathrm{CS}$ and $\mathrm{HC}$.

The study was performed according to the Helsinki Declaration II with written informed consent obtained from all patients and approval by the Local Ethics Committee.

\section{Statistical analysis}

Data are expressed as mean \pm s.D. with the KolmogorovSmirnov test applied to verify the normal distribution of quantitative variables. Based on data distribution, comparison of continuous variables between the two groups was performed by the Student's $t$-test or the Mann-Whitney rank sum test. One-way ANOVA or Kruskal-Wallis ANOVA was used to compare variables between different groups and the Bonferroni test for post-hoc analysis. Categorical variables were analyzed by the $\chi^{2}$ test or Fisher's exact test if appropriate. Logistic regression analysis was used to assess the association between the presence of T2DM (dependent variable) and the presence of A3669G GR polymorphism corrected by confounding factors (independent variables). Significance was set at $P<0.05$. Statistical analysis was performed by SPSS Software version 18.0 (SPSS, Inc., Chicago, IL, USA).

\section{Results}

Genotype distributions and allele frequencies of the four GR gene polymorphisms in patients with CS and in HC were summarized in Table 1. 
Table 2 Clinical and biochemical features of patients with Cushing's syndrome $(n=52)$ according to Bcl1 haplotype. Data are expressed as mean \pm s.D. or absolute number (percentage in parentheses).

\begin{tabular}{lccc}
\hline & WT & Bcl1 carrier & \\
& $(n=21)$ & $(n=31)$ & $P$ \\
\hline CD (\%) & $15(71.4)$ & $23(74.2)$ & 1.00 \\
Age (years) & $45.2 \pm 14.5$ & $44.7 \pm 13.5$ & 0.90 \\
Female (\%) & $18(86)$ & $25(81)$ & 0.72 \\
BMl $\left(\mathrm{kg} / \mathrm{m}^{2}\right)$ & $30.6 \pm 7.0$ & $28.0 \pm 5.3$ & 0.13 \\
Duration of disease (months) & $61.6 \pm 63.0$ & $64 \pm 73.3$ & 0.91 \\
Morning serum cortisol $(\mu \mathrm{g} / \mathrm{dl})$ & $21.2 \pm 7.0$ & $25.9 \pm 7.6$ & 0.029 \\
Midnight serum cortisol $(\mu \mathrm{g} / \mathrm{dll})$ & $18.92 \pm 7.72$ & $22.24 \pm 6.63$ & 0.10 \\
UFC $(\mu \mathrm{g} / 24 \mathrm{~h})$ & $218 \pm 224$ & $268 \pm 298$ & 0.56 \\
1 mg DST ( $\mu \mathrm{g} / \mathrm{dl})$ & $17.4 \pm 10$ & $17.4 \pm 8.5$ & 0.98 \\
HOMA-IR & $3.6 \pm 1.9$ & $2.7 \pm 1.7$ & 0.09 \\
HOMA $\beta$-cell $(\%)$ & $197 \pm 133$ & $153 \pm 129$ & 0.37 \\
Arterial hypertension $(\%)$ & $19(90.5)$ & $28(90.3)$ & 1.00 \\
Type 2 diabetes mellitus (\%) & $7(33)$ & $18(58)$ & 0.097 \\
Dyslipidemia (\%) & $15(71)$ & $11(35)$ & 0.16 \\
Obesity (\%) & $12(57)$ & $26(83)$ & 0.75 \\
\hline
\end{tabular}

WT, wild type; Bcl1 carrier, patients with heterozygous or homozygous $\mathrm{Bcl} 1$ polymorphism; $C D$, Cushing's disease; BMI, body mass index; UFC, urinary free cortisol; $1 \mathrm{mg}$ DST, serum cortisol after $1 \mathrm{mg}$ dexamethasone suppression test (to convert serum cortisol to $\mathrm{nmol} / \mathrm{l}$ multiply by 27.6 ; to convert urine cortisol to $\mathrm{nmol} / \mathrm{l}$ multiply by 2.7 )

Our data showed a markedly higher prevalence of the BclI variant of the GR gene in patients with CS than in $\mathrm{HC}(62.3$ vs $40.8 \%, P<0.05)$. No significant differences were found in the allelic frequencies of the others three GR polymorphisms (A3669G, N363S, and ER22/23EK).

When patients with CS were divided into CD and ACS and then considered separately, no significant difference was observed in the Bcl1 carrier frequency between the two groups ( 61 vs $65 \%, P>0.05$ ). When each group was compared with $\mathrm{HC}$ statistical significance was found only between $\mathrm{CD}$ and $\mathrm{HC}$ (61 vs $41 \%, P<0.05$ ), probably reflecting the lower number of patients with ACS.

Nine patients with CS were excluded from clinical and biochemical statistical evaluation for incomplete data. Clinical and biochemical features of the 52 patients with CS investigated are shown in Supplementary Table 2, see section on supplementary data given at the end of this article. Of the total, 38 patients had CD and 14 patients had ACS. Patients with CD compared with ACS showed increased levels of both morning $(25.9 \pm 7.9$ vs $18.8 \pm 4.2 \mu \mathrm{g} / \mathrm{dl} ; 714.8 \pm 218.0$ vs $518.9 \pm 115.9 \mathrm{nmol} / \mathrm{l}, P=0.003)$ and midnight serum cortisol $(22.1 \pm 7.0 \mathrm{vs} 17.4 \pm 7 \mu \mathrm{g} / \mathrm{dl} ; 609.9 \pm 193.2 \mathrm{vs}$ $480.2 \pm 193.2 \mathrm{nmol} / \mathrm{l}, \quad P=0.039)$ and a longer duration of disease.

Because of the low frequency of the N363S and the ER22/23EK GR polymorphisms found, only the BcII and the A3669G GR gene variants was evaluated for the potential association with hormonal, clinical, and metabolic parameters in patients with CS.

No CS patients expressed all four GR polymorphisms whereas 12 CS patients coexpressed the BclI and
A3669G GR gene variants. Three N363S carriers coexpressed the BclI GR polymorphism while the three ER22/23EK carriers coexpressed the A3669G GR gene variant.

The three patients carrying the N363S GR polymorphism were: two patients with $\mathrm{CD}$ (one, 55-year-old female and one, 14-year-old male) and one patient with ACS (a 30-year-old female); all three patients were affected by hypertension. In contrast, the three patients with the ER22/23EK GR polymorphism all had CD and showed dyslipidemia (two, 59- and 32-year-old female and one, 35-year-old male).

Clinical and biochemical features of patients with CS according to Bcl1 and A3669 haplotype were summarized in Tables 2 and 3 respectively.

No significant differences were found when homozygous and heterozygous were analyzed separately. For this reason and considering the very small number of homozygous, we decided to consider homozygous and heterozygous as a single group of patients defined as 'carriers'.

Because the increased levels of serum cortisol and the longer duration of disease found in CD compared with ACS, we take into account also the distribution of $\mathrm{CD}$ among 'carriers' and wild type found no significant differences (Tables 2 and 3).

Our data showed that BclI carriers compared with wild type had higher levels of serum morning cortisol $(25.9 \pm 7.6$ vs $21.2 \pm 7.0 \mu \mathrm{g} / \mathrm{dl} ; 714.8 \pm 209.7$ vs $585.1 \pm 193.2 \mathrm{nmol} / \mathrm{l}, P=0.029)$ but no different levels of either midnight serum or UFC, similarly no clinical

Table 3 Clinical and biochemical features of patients with Cushing's syndrome $(n=52)$ according to A3669G haplotype. Data are expressed as mean \pm S.D. or absolute number (percentage in parentheses).

\begin{tabular}{lccc}
\hline & WT & A3669G & \\
& $(n=31)$ & $\begin{array}{c}\text { carrier } \\
(n=21)\end{array}$ & $\boldsymbol{P}$ \\
\hline CD (\%) & $20(64.5)$ & $18(85.7)$ & 0.11 \\
Age (years) & $47.9 \pm 11.6$ & $40.5 \pm 15.7$ & 0.58 \\
Female (\%) & $26(84)$ & $17(81)$ & 1.00 \\
BMI (kg/m ${ }^{2}$ ) & $29.9 \pm 5.7$ & $28.0 \pm 6.7$ & 0.28 \\
Duration of disease (months) & $60.5 \pm 60.2$ & $65.71 \pm 77.7$ & 0.80 \\
Morning serum cortisol ( $\mu \mathrm{g} / \mathrm{dl})$ & $21.7 \pm 6.1$ & $27.3 \pm 8.6$ & 0.009 \\
Midnight serum cortisol ( $\mu \mathrm{g} / \mathrm{dl})$ & $18.8 \pm 5.9$ & $24.0 \pm 8.0$ & 0.01 \\
UFC ( $\mu$ g/24 h) & $257 \pm 272$ & $235 \pm 272$ & 0.79 \\
1 mg DST ( $\mu \mathrm{g} / \mathrm{dl})$ & $16.5 \pm 8.9$ & $18.65 \pm 9.3$ & 0.42 \\
HOMA-IR & $2.2 \pm 1.5$ & $3.3 \pm 1.7$ & 0.089 \\
HOMA $\beta$-cell (\%) & $148 \pm 130$ & $200 \pm 128$ & 0.29 \\
Arterial hypertension (\%) & $29(93)$ & $18(86)$ & 0.38 \\
Type 2 diabetes mellitus (\%) & $21(68)$ & $4(19)$ & 0.001 \\
Dyslipidemia (\%) & $26(84)$ & $15(71)$ & 0.31 \\
Obesity (\%) & $16(52)$ & $7(33 \%)$ & 0.25 \\
\hline
\end{tabular}

WT, wild type; A3669G carrier, patients with heterozygous or homozygous A3669G polymorphism; CD, Cushing's disease; BMI, body mass index; UFC urinary free cortisol; $1 \mathrm{mg}$ DST, serum cortisol after $1 \mathrm{mg}$ dexamethasone suppression test (to convert serum cortisol to $\mathrm{nmol} / \mathrm{l}$ multiply by 27.6 ; to convert urine cortisol to $\mathrm{nmol} / \mathrm{l}$ multiply by 2.7 ). 
Table 4 Association of T2DM with A3669G GR polymorphism in Cushing's syndrome patients adjusted for confounding factors.

\begin{tabular}{llc}
\hline & \multicolumn{1}{c}{ T2DM } \\
& \multicolumn{1}{c}{$($ OR $(95 \% \mathrm{Cl}))$} & $\boldsymbol{P}$ \\
\hline A3669G (pres. vs abs.) & $0.06(0.009-0.51)$ & 0.01 \\
Bcl1 (pres. vs abs.) & $9.83(1.13-85.02)$ & 0.03 \\
ER22/23EK (pres. vs abs.) & $7.00(0.13-368.33)$ & 0.33 \\
Gender (F vs M) & $0.14(0.007-3.19)$ & 0.22 \\
Age (1 year increase) & $1.05(0.98-1.12)$ & 0.16 \\
Familial diabetes (pres. vs abs.) & $0.24(0.03-1.73)$ & 0.15 \\
BMI (1 kg/m ${ }^{2}$ increase) & $1.18(0.98-1.43)$ & 0.07 \\
Dur. of disease (1 month increase) & $0.98(0.96-1.00)$ & 0.07 \\
\hline
\end{tabular}

OR, odds ratio; BMI, body mass index; pres., presence; abs., absence; $\mathrm{F}$, female; $\mathrm{M}$, male; Dur., duration.

or metabolic differences were found between the two groups of patients (Table 2).

In contrast, the presence of the A3669G GR polymorphism was associated with a reduced prevalence of type 2 diabetes in A3669G carriers compared with wild type (19 vs $68 \%, P=0.001$ ) despite the higher levels of both morning $(27.3 \pm 8.6$ vs $21.7 \pm 6.1 \mu \mathrm{g} / \mathrm{dl} ; 753.4 \pm$ 237.3 vs $598.9 \pm 168.3 \mathrm{nmol} / \mathrm{l}, P=0.009)$ and midnight serum cortisol $(24.0 \pm 8.0$ vs $18.8 \pm 5.9 \mu \mathrm{g} / \mathrm{dl} ; 662.4 \pm$ 220.8 vs $518.9 \pm 162.8 \mathrm{nmol} / \mathrm{l}, P=0.01)$ found in this group of patients (Table 3 ).

Considering the linkage between the A3669G and the ER22/23EK GR gene variants, we performed all the evaluations analyzing A3669G without ER22/23EK and found no significant differences (data not shown).

In Table 4, we report the association (measured by the odds ratio) with T2DM and A3669G GR polymorphism adjusted for potential confounding factors (BclI and ER22/23EK coexpression, age, sex, BMI, familial diabetes, and duration of disease). Logistic regression analysis showed that the presence of the A3669G was associated with a lower risk of DM regardless of age, sex, BMI, familial diabetes, duration of disease, and BclI and ER22/23EK coexpression. The logistic regression analysis showed also that the presence of the BclI GR gene variant was associated with an increased risk of developing DM.

When CS patients were considered according to their genotype (wild type, BclI carriers, A3669G carriers, and patients coexpressing BclI and A3669G GR polymorphisms), A3669G carriers still showed a reduced prevalence of $\mathrm{T} 2 \mathrm{DM}$ that resulted in statistically significance compared with BclI carriers (11 vs $79 \%, P=0.001)$ and with a trend of significance compared with wild type ( 11 vs $50 \%, P=0.07$ ). Even when the A3669G GR gene variant was expressed in association with the BclI GR polymorphism, the patients showed a lower prevalence of T2DM compared with BclI carriers (25 vs $79 \%, P=0.008$; Fig. 1 ).

\section{Discussion}

In this study, we found that the BclI variant of the GR gene was significantly more frequent in patients with CS than in $\mathrm{HC}$ and that patients with $\mathrm{CD}$ and ACS have a similar prevalence of this variant. While the prevalence of this GR polymorphism in our CS is in line with that recently reported by Szappanos et al. (27), the allele frequency found in our control group is lower compared with that previously reported $(\sim 35 \%)$ in healthy subjects $(12-14,34,35)$. Although the significance of our finding is therefore uncertain, the potential role of the BclI GR polymorphism in susceptibility to develop endogenous hypercortisolism should be taken into account and is worthy of further investigation.

Several previous studies have shown that polymorphisms of the GR are associated with altered sensitivity to GCs: in particular, the BclI polymorphisms of the GR gene have been associated with an enhanced sensitivity to GCs and consequently to a worse metabolic and bone profile in the general population $(10,12-15)$. Patients with subclinical hypercortisolism were recently investigated by Morelli et al. (36) to evaluate the role of the GR polymorphisms in metabolic or bone alterations in patients with adrenal incidentalomas (AI) without features of overt hypercortisolism. They found an increased frequency of arterial hypertension (alone or in combination with vertebral fractures) in patients with AI carrying the homozygous BclI GR gene variant (such as the heterozygous N363S GR polymorphism) with or without subclinical hypercortisolism, suggesting a possible role for $G R$ polymorphisms in this group of patients in determining the metabolic and bone complications typical of overt cortisol excess.

In patients with overt CS only the role of $G R$ polymorphisms on bone metabolism has been

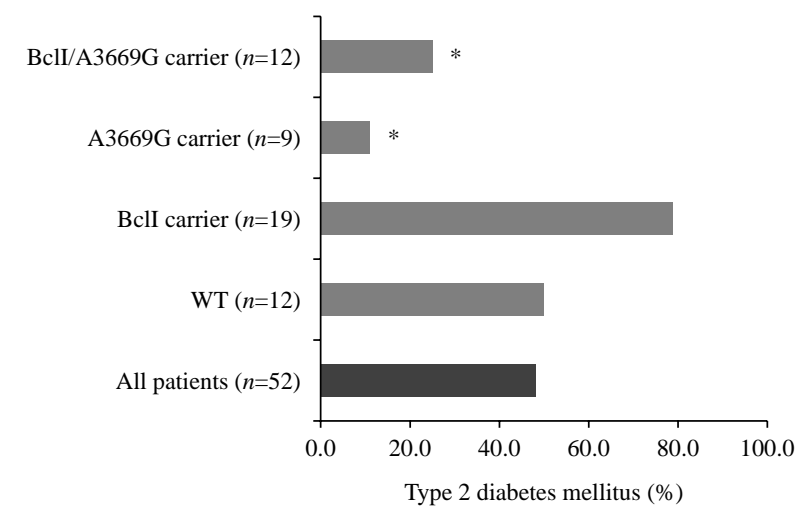

Figure 1 Type 2 diabetes mellitus frequency in patients with Cushing's syndrome (CS) according to haplotype. WT, wild type; Bcll carrier, patients with heterozygous or homozygous Bcll polymorphism; A3669G carrier, patients with heterozygous or homozygous A3669G polymorphism; Bcll/A3669G carrier, patients coexpressing Bcll and $A 3669$ GR polymorphisms. ${ }^{\star} P<0.05$ vs Bcll carrier. 
investigated. In particular, Szappanos et al. (27) found increased skeletal sensitivity to GCs in CS patients carrying the BclI GR polymorphism compared with wild type.

To our knowledge, our study is the first to analyze the potential role of the $G R$ gene variants in the development of clinical and metabolic complications in patients with overt endogenous hypercortisolism.

In our study, contrary to that reported by Morelli et al. (36) in patients with AI, the BclI GR polymorphism was not associated with an increased prevalence of arterial hypertension. The logistic regression analysis showed however an association between the presence of the BclI GR gene variant and an increased risk of developing DM. BclI carriers showed also increased levels of serum morning cortisol compared with wild type, but no differences in BMI, HOMA parameters, or lipid profile were found between the two groups.

The main result of our study was the low frequency of T2DM in patients with the A3669G GR polymorphism, a finding not previously reported. We found that the A3669G carriers showed a significant reduced prevalence of this metabolic alteration compared with wild type (19 vs $68 \%, P<0.05)$, despite increased levels of serum morning and midnight cortisol. The significance of this finding persisted even when the A3669G carriers were divided into two groups according to the BcII GR gene variant coexpression. In particular, one patient of the nine A3669G carriers and three patients of the twelve coexpressing the two GR polymorphisms A3669G and BclI were affected by DM. These findings, in addition to the increased risk of developing DM associated with BcII, reinforce the protective role of $\mathrm{A} 3669 \mathrm{G}$ able to reduce the risk of DM even when coexpressed with Bcl1.

The negative association between DM and the A3669G GR polymorphism remained significant when data were adjusted for potential confounding factors (such as age, sex, BMI, familial diabetes, duration of disease, and BclI coexpression). Considering the linkage between the A3669G and the ER22/23EK GR gene variants we added the coexpression of ER22/23EK in the logistic regression analysis as a potential confounding factor. The association between A3669G GR polymorphism and the lower risk of developing DM remained statistically significant even after this adjustment. All these findings suggest therefore a dominant role for the A3669G in patients with CS able to module the GR sensitivity with a selective protective role from the negative effects of GCs excess on glucose metabolism.

The effects of GCs are mediated by GR- $\alpha$, the functional $G R$ isoform. An alternative isoform, GR- $\beta$, behaves as a dominant-negative inhibitor of $G R-\alpha$ and has been implicated as a factor contributing to GC resistance. The A3669G GR polymorphism, located in the $3^{\prime}$ end of exon $9 \beta$, results in increased stability of GR- $\beta$ mRNA and increased GR- $\beta$ protein expression; this may lead to greater inhibition of GR- $\alpha$ transcriptional activity and consequently reduced sensitivity to
GCs. Previous investigations have indeed associated the A3669G GR polymorphism with relative GC resistance due to decreased GR- $\alpha$ transcriptional activity (19-26).

The major limit of our study was the limited number of CS patients studied. It should be remembered, however, that CS is a rare disorder with an estimated annual incidence of 2.3 million/year (2). Although the amount of CS patients in our study was relatively small, the number was sufficient to detect significant findings not previously reported about the potential protective role of this GR polymorphism on glucose metabolism alterations. DM is a common complication of CS interesting ranging from 20 to $50 \%$ of patients with overt endogenous hypercortisolism (7). This prevalence is however probably underestimated because alterations in glucose metabolism are not always investigated, and an OGTT is not always performed in patients with active CS.

In our study, the diagnosis of T2DM was made according to the criteria revised on 2003 by the American Diabetes Association (31) and, by these criteria, the prevalence of altered glucose metabolism was $48 \%$. GC excess increases the expression of several key enzymes involved in liver gluconeogenesis and thus increased production of glucose; they also play an important role in the development of both insulin resistance and impaired $\beta$-cell function $(7,37,38)$.

In our study, insulin resistance and $\beta$-cell function in patients with CS was investigated by measuring HOMAIR and HOMA $\beta$-cell. We found no differences in these parameters in A3669G carriers compared with wild type. On this basis decreased stimulation of liver gluconeogenesis by GCs excess in patients with the A3669G GR polymorphism may explain the lower prevalence of DM observed.

In summary, we evaluated the four polymorphisms of the GR gene in CS for potential association of these gene variants with clinical or metabolic complications typically seen in overt hypercortisolism. We excluded ectopic CS and patients with cortisol-secreting adrenal carcinoma from the evaluation to investigate a homogeneous group of patients and minimize confounding factors. As potential confounding factors, the coexpression of more than one polymorphisms was also considered. Our results suggest a protective role of the A3669G polymorphism of the GR gene in patients with CS that attenuates the effects of GCs excess on glucose metabolism, and thus a reduced risk of developing DM.

\section{Supplementary data}

This is linked to the online version of the paper at http://dx.doi.org/10. 1530/EJE-11-0722.

\section{Declaration of interest}

The authors declare that there is no conflict of interest that could be perceived as prejudicing the impartiality of the research reported. 


\section{Funding}

This research did not receive any specific grant from any funding agency in the public, commercial or not-for-profit sector.

\section{References}

1 Etxabe J \& Vazquez JA. Morbidity and mortality in Cushing's disease: an epidemiological approach. Clinical Endocrinology 1994 40 479-484. (doi:10.1111/j.1365-2265.1994.tb02486.x)

2 Lindholm J, Juul S, Jorgensen JO, Astrup J, Bjerre P, FeldtRasmussen U, Hagen C, Jorgensen J, Kosteljanetz M, Kristensen L, Laurberg P, Schmidt K \& Weeke J. Incidence and late prognosis of Cushing's syndrome: a population-based study. Journal of Clinical Endocrinology and Metabolism 200186 117-123. (doi:10.1210/jc. 86.1.117)

3 Orth DN. Cushing's syndrome. New England Journal of Medicine 1995332 791-803. (doi:10.1056/NEJM199503233321207)

4 Boscaro M, Barzon L, Fallo F \& Sonino N. Cushing's syndrome. Lancet $2001 \quad 357 \quad 783-791 . \quad$ (doi:10.1016/S0140-6736(00) 04172-6)

5 Bertagna X, Raux-Demay MC, Guilhaume B, Girard F \& Luton JP. Cushing's disease. In The Pituitary, pp 592-612. Ed. S Melmed, Cambridge: Blackwell, 1995.

6 Newell-Price J. Trainer P. Besser GM \& Grossman AB. The diagnosis and differential diagnosis of Cushing's syndrome and pseudo-Cushing's states. Endocrine Reviews 199819 647-672. (doi:10.1210/er.19.5.647)

7 Arnaldi G, Angeli A, Atkinson AB, Bertagna X, Cavagnini F, Chrousos GP, Fava GA, Findling JW, Gaillard RC, Grossman AB, Kola B, Lacroix A, Mancini T, Mantero F, Newell-Price J, Nieman LK, Sonino N, Vance ML, Giustina A \& Boscaro M. Diagnosis and complications of Cushing's syndrome: a consensus statement. Journal of Clinical Endocrinology and Metabolism 2003 88 5593-5602. (doi:10.1210/jc.2003-030871)

8 Huizenga NA, Koper JW, de Lange P, Pols HA, Stolk RP, Grobbee DE, de Jong FH \& Lamberts SW. Interperson variability but intraperson stability of baseline plasma cortisol concentrations, and its relation to feedback sensitivity of the hypothalamo-pituitary-adrenal axis to a low dose of dexamethasone in elderly individuals. Journal of Clinical Endocrinology and Metabolism 199883 47-54. (doi:10.1210/jc.83.1.47)

9 Zhou J \& Cidlowski JA. The human glucocorticoid receptor: one gene, multiple proteins and diverse responses. Steroids $2005 \mathbf{7 0}$ 407-417. (doi:10.1016/j.steroids.2005.02.006)

10 Manenschijn L, van den Akker Erica LT, Lamberts Steven WJ \& van Rossum Elisabeth FC. Clinical features associated with glucocorticoid receptor polymorphisms: an overview. Annals of the New York Academy of Sciences 20091179 179-198. (doi:10. $1111 /$ j.1749-6632.2009.05013.x)

11 Huizenga NA, Koper JW, De Lange P, Pols HA, Stolk RP, Burger H, Grobbee DE, Brinkmann AO, De Jong FH \& Lamberts SW. A polymorphism in the glucocorticoid receptor gene may be associated with and increased sensitivity to glucocorticoids in vivo. Journal of Clinical Endocrinology and Metabolism $1998 \mathbf{8 3}$ 144-151. (doi:10.1210/jc.83.1.144)

12 van Rossum EF, Koper JW, van den Beld AW, Uitterlinden AG, Arp P, Ester W, Janssen JA, Brinkmann AO, de Jong FH, Grobbee DE, Pols HA \& Lamberts SW. Identification of the BclI polymorphism in the glucocorticoid receptor gene: association with sensitivity to glucocorticoids in vivo and body mass index. Clinical Endocrinology 200359 585-592. (doi:10.1046/j.13652265.2003.01888.x)

13 van Rossum EF \& Lamberts SW. Polymorphisms in the glucocorticoid receptor gene and their associations with metabolic parameters and body composition. Recent Progress in Hormone Research 200459 333-357. (doi:10.1210/rp.59.1.333)
14 van Schoor NM, Dennison E, Lips P, Uitterlinden AG \& Cooper C. Serum fasting cortisol in relation to bone, and the role of genetic variations in the glucocorticoid receptor. Clinical Endocrinology 200767 871-878. (doi:10.1111/j.1365-2265.2007.02978.x)

15 Di Blasio AM, van Rossum EF, Maestrini S, Berselli ME, Tagliaferri M, Podestá F, Koper JW, Liuzzi A \& Lamberts SW. The relation between two polymorphisms in the glucocorticoid receptor gene and body mass index, blood pressure and cholesterol in obese patients. Clinical Endocrinology 200359 68-74. (doi:10. 1046/j.1365-2265.2003.01798.x)

16 van Rossum EF, Koper JW, Huizenga NA, Uitterlinden AG, Janssen JA, Brinkmann AO, Grobbee DE, de Jong FH, van Duyn CM, Pols HA \& Lamberts SW. A polymorphism in the glucocorticoid receptor gene, which decreases sensitivity to glucocorticoids in vivo, is associated with low insulin and cholesterol levels. Diabetes 200251 3128-3134. (doi:10.2337/ diabetes.51.10.3128)

17 van Rossum EF, Voorhoeve PG, te Velde SJ, Koper JW, Delemarrevan de Waal HA, Kemper HC \& Lamberts SW. The ER22/23EK polymorphism in the glucocorticoid receptor gene is associated with a beneficial body composition and muscle strength in young adults. Journal of Clinical Endocrinology and Metabolism $2004 \mathbf{8 9}$ 4004-4009. (doi:10.1210/jc.2003-031422)

18 van Rossum EF, Feelders RA, van den Beld AW, Uitterlinden AG, Janssen JA, Ester W, Brinkmann AO, Grobbee DE, de Jong FH, Pols HA, Koper JW \& Lamberts SW. Association of the ER22/23EK polymorphism in the glucocorticoid receptor gene with survival and C-reactive protein levels in elderly men. American Journal of Medicine 2004117 158-162. (doi:10.1016/j.amjmed.2004.01.027)

19 Oakley RH, Sar M \& Cidlowski JA. The human glucocorticoid receptor beta isoform. Expression, biochemical properties and putative function. Journal of Biological Chemistry 1996271 9550-9559. (doi:10.1074/jbc.271.16.9550)

20 Bamberger CM, Bamberger AM, de Castro M \& Chrousos GP. Glucocorticoid receptor beta, a potential endogenous inhibitor of glucocorticoid action in humans. Journal of Clinical Investigation 199595 2435-2441. (doi:10.1172/JCI117943)

21 Oakley RH, Jewell CM, Yudt MR, Bofetiado DM \& Cidlowski JA. The dominant negative activity of the human glucocorticoid receptor beta isoform. Specificity and mechanisms of action. Journal of Biological Chemistry 1999274 27857-27866. (doi:10.1074/jbc. 274.39.27857)

22 Leung DY, Hamid Q, Vottero A, Szefler SJ, Surs W, Minshall E, Chrousos GP \& Klemm DJ. Association of glucocorticoid insensitivity with increased expression of glucocorticoid receptor beta. Journal of Experimental Medicine 1997186 1567-1574. (doi:10.1084/jem.186.9.1567)

23 Schaaf MJ \& Cidlowski JA. AUUUA motifs in the $3^{\prime}$ UTR of human glucocorticoid receptor alpha and beta mRNA destabilize mRNA and decrease receptor protein expression. Steroids 200267 627-636. (doi:10.1016/S0039-128X(02)00015-6)

24 de Castro M, Elliot S, Kino T, Bamberger C, Karl M, Webster E \& Chrousos GP. The non-ligand binding beta-isoform of the human glucocorticoid receptor (hGR beta): tissue levels, mechanism of action, and potential physiologic role. Molecular Medicine 19962 597-607.

25 van den Akker EL, Koper JW, van Rossum EF, Dekker MJ, Russcher H, de Jong FH, Uitterlinden AG, Hofman A, Pols HA, Witteman JC \& Lamberts SW. Glucocorticoid receptor gene and risk of cardiovascular disease. Archives of Internal Medicine 2008 168 33-39. (doi:10.1001/archinternmed.2007.41)

26 Syed AA, Irving JA, Redfern CP, Hall AG, Unwin NC, White M, Bhopal RS \& Weaver JU. Association of glucocorticoid receptor polymorphism A3669G in exon 9beta with reduced central adiposity in women. Obesity 200614 759-764. (doi:10.1038/oby.2006.86)

27 Szappanos A, Patócs A, Tõke J, Boyle B, Sereg M, Majnik J, Borgulya G, Varga I, Likó I, Rácz K \& Tóth M. BclI polymorphism of the glucocorticoid receptor gene is associated with decreased bone mineral density in patients with endogenous hypercortisolism. Clinical Endocrinology 200971 636-643. (doi:10.1111/j.13652265.2009.03528.x) 
28 Nieman LK, Biller BM, Findling JW, Newell-Price J, Savage MO, Stewart PM \& Montori VM. The diagnosis of Cushing's syndrome: an Endocrine Society Clinical Practice Guideline. Journal of Clinical Endocrinology and Metabolism 200893 152-640. (doi:10.1210/ jc.2008-0125)

29 Laragh JH \& Brenner BM. In Hypertension: Pathophysiology, Diagnosis and Management, 2nd edn, pp 1987. Raven Press: New York, 1995.

30 Expert Panel on Detection, Evaluation and Treatment of High Blood Cholesterol in Adults. Executive summary of the Third Report of the National Cholesterol Education Program (NCEP) Expert Panel on Detection, Evaluation and Treatment of High Blood Cholesterol in Adults (Adult Treatment Panel III). Journal of the American Medical Association 2001285 2486-2497. (doi:10. 1001/jama.285.19.2486)

31 The Expert Committee on the Diagnosis and Classification of Diabetes Mellitus. Report of the Expert Committee on the Diagnosis and Classification of Diabetes Mellitus. Diabetes Care 200326 S5-S20. (doi:10.2337/diacare.26.2007.S5)

32 Matthews DR, Hosker JP, Rudenski AS, Naylor BA, Treacher DF \& Turner RC. Homeostasis model assessment: insulin resistance and beta-cell function from fasting plasma glucose and insulin concentrations in man. Diabetologia 198528 412-419. (doi:10. 1007/BF00280883)

33 Santos-Montes A, Gonzalo-Lumbreras R \& Izquierdo-Hornillos R. Simultaneous determination of cortisol and cortisone in urine by reversed-phase high-performance liquid chromatography. Clinic and doping control application. Journal of Chromatography 1995 673 27-33. (doi:10.1016/0378-4347(95)00253-F)
34 Tremblay A, Bouchard L, Bouchard C, Després JP, Drapeau V \& Pérusse L. Long-term adiposity changes are related to a glucocorticoid receptor polymorphism in young females. Journal of Clinical Endocrinology and Metabolism $2003 \mathbf{8 8}$ 3141-3145. (doi:10.1210/jc.2002-021521)

35 Ukkola O, Pérusse L, Chagnon YC, Després JP \& Bouchard C. Interactions among the glucocorticoid receptor, lipoprotein lipase and adrenergic receptor genes and abdominal fat in Québec Family Study. International Journal of Obesity and Related Metabolic Disorders 200125 1332-1339. (doi:10.1038/sj.ijo.0801735)

36 Morelli V, Donadio F, Eller-Vainicher C, Cirello V, Olgiati L, Savoca C, Cairoli E, Salcuni AS, Beck-Peccoz P \& Chiodini I. Role of glucocorticoid receptor polymorphism in adrenal incidentalomas. European Journal of Clinical Investigation 201040 803-811. (doi:10.1111/j.1365-2362.2010.02330.x)

37 Pivonello R, De Leo M, Vitale P, Cozzolino A, Simeoli C, De Martino MC, Lombardi G \& Colao A. Pathophysiology of diabetes mellitus in Cushing's Syndrome. Neuroendocrinology 2010 92 (Suppl 1) 77-81. (doi:10.1159/000314319)

38 Mancini T, Kola B, Mantero F, Boscaro M \& Arnaldi G. High cardiovascular risk in patients with Cushing's syndrome according to 1999 WHO/ISH guidelines. Clinical Endocrinology 2004 61 768-777. (doi:10.1111/j.1365-2265.2004.02168.x)

Received 16 August 2011

Revised version received 19 October 2011

Accepted 27 October 2011 